\title{
Health of new beta-glucan rich hull-less barley lines
}

\section{Zdrowotność ziarna nowych rodów jęczmienia nieoplewionego o podwyższonej zawartości beta-glukanów}

\author{
Zygmunt Gil, Agnieszka Mularczyk
}

\section{Summary}

The aim of the study was to determine the occurrence of fungi species on grain of hull-less barley grain (STH 1192, STH 1246, STH 1292, STH 4933, STH 7007 and STH 7089 - cultivar Gawrosz). The tested grain was obtained from the Plant Breeding Strzelce Ltd., IHAR group. The results were analyzed basing on the principal component analysis (PCA).

It was found that the grain health condition was good. The differences in the frequency of occurrence of particular fungus species were stated between non-disinfected and disinfected grain. Over a half of the variability of the results was caused by the presence of so classified "other" fungi, and Alternaria alternata. On the other hand, 1/5 of the result variability was conditioned by the presence of species Epicoccum nigrum and Fusarium poae. The lines, which were highly infected by E. nigrum were less infected by $F$. poae. After surface disinfection less than $40 \%$ of the result variability was related to the occurrence of $A$. alternata and $E$. nigrum as well as the "other" fungi. Also $30 \%$ of the result variability was caused by the presence of Fusarium graminearum and $F$. poae, and $A$. alternata.

Key words: hull-less barley, health, grain

\section{Streszczenie}

Badano zasiedlenie przez grzyby strzępkowe ziarna nowych rodów jęczmienia nieoplewionego: STH 1192, STH 1246, STH 1292, STH 4933, STH 7007 i STH 7089 (odmiana Gawrosz). Ziarno otrzymano z Hodowli Roślin Strzelce Sp. z o.o. grupa IHAR. Wyniki omówiono w oparciu o analizę głównych składowych (PCA - principal component analysis).

Stan fitosanitarny badanego ziarna był dobry, zauważono jednak różnice w częstotliwości występowania grzybów pomiędzy ziarnem nieodkażonym i odkażonym. W przypadku powierzchni ziarna, ponad połowa zmienności uzyskanych wyników była spowodowana obecnością grzybów sklasyfikowanych jako „pozostałe” i Alternaria alternata. Natomiast o $1 / 5$ zmienności decydowała przede wszystkim obecność Epicoccum nigrum i Fusarium poae. Rody, które były silniej zasiedlone przez E. nigrum, w mniejszym stopniu były zainfekowane przez F. poae. Po powierzchniowym odkażeniu ziarna niecałe $40 \%$ zmienności uzyskanych wyników zależało od obecności A. alternata oraz E. nigrum i grzybów sklasyfikowanych jako „pozostałe”. Z kolei 30\% zmienności wynikało przede wszystkim z obecności Fusarium graminearum, F. poae oraz A. alternata.

Słowa kluczowe: jęczmień nagoziarnowy, zdrowotność, ziarno

Uniwersytet Przyrodniczy we Wrocławiu Zakład Technologii Zbóż

Chełmońskiego 37/41, 51-630 Wrocław

zygmunt.gil@up.wroc.pl 


\section{Wstęp / Introduction}

Jęczmień jest jednym z ważniejszych zbóż i chociaż głównymi kierunkami jego użytkowania są przemysł paszowy i browarniczy, zaczyna być postrzegany jako ważny składnik diety. Dzieje się tak dzięki wysokiej zawartości beta-glukanów o udowodnionym działaniu prozdrowotnym. Obniżają one poziom cholesterolu we krwi, poprawiają metabolizm tłuszczów, obniżają indeks glikemiczny i zmniejszają ryzyko chorób serca (Gil i wsp. 2011).

W ostatnich latach rośnie zainteresowanie jęczmieniem nieoplewionym ze względu na jego unikalne cechy $\mathrm{w}$ porównaniu $\mathrm{z}$ jęczmieniem oplewionym. Jęczmień ten nie wymaga obłuskiwania, dzięki czemu ułatwiony jest jego przerób. Zawiera więcej białka o wysokiej wartości biologicznej i większy udział frakcji rozpuszczalnych błonnika przy mniejszej jego całkowitej ilości (Gil i wsp. 2011, 2012).

Obecność grzybów zasiedlających powierzchnię ziarna jęczmienia ma istotne znaczenie dla jego jakości. Mogą one się rozmnażać w czasie magazynowania i słodowania, co wiąże się z pogorszeniem właściwości ziarna i słodu oraz ryzykiem powstawania niebezpiecznych dla zdrowia mikotoksyn (Rabie i wsp. 1997). Porażone ziarno ma obniżoną masę 1000 ziaren i masę objętościową, zawiera mniej białka, a gluten pszenny charakteryzuje się zwiększoną rozpływalnością. Znane są również przypadki wpływu grzybów i ich metabolitów na kiełkowanie, tworzenie $\alpha$-amylazy, a nawet fermentację poprzez ujemny wpływ na drożdże (Rabie i wsp. 1997; Narkiewicz-Jodko 1998).

Celem badań było zbadanie zasiedlenia ziarna jęczmienia nagiego przez grzyby strzępkowe.

\section{Materiały i metody / Materials and methods}

Materiał stanowiło ziarno nowych rodów jęczmienia nieoplewionego: STH 1192, STH 1246, STH 1292, STH
4933, STH 7007 i STH 7089 (odmiana Gawrosz). Ziarno otrzymano z Hodowli Roślin Strzelce Sp. z o.o. grupa IHAR. Po zbiorze ziarno przechowywano $\mathrm{w}$ temperaturze pokojowej przy względnej wilgotności powietrza około $30 \%$.

Do oceny zdrowotności pobrano po 200 ziarniaków. $100 \mathrm{z}$ nich wyłożono na pożywkę maltozowo-agarową (2\% maltozy i $2 \%$ agaru), a kolejne 100 przed wyłożeniem odkażano w $1 \%$ podchlorynie sodu przez 10 minut. Szalki z wyłożonym ziarnem inkubowano przez 2 tygodnie w temperaturze $22^{\circ} \mathrm{C}$, po czym wyrosłe kolonie przeszczepiono na skosy maltozowo-agarowe, a następnie dokonano ich identyfikacji na podstawie kluczy (Malone i Muskett 1964; Booth 1971; Ellis 1971; Barnett i Hunter 1972).

Współzależności występowania poszczególnych gatunków grzybów przeprowadzono w oparciu o korelację liniową Pearsona, a zmienność rodów - na podstawie analizy głównych składowych (PCA - principal component analysis).

\section{Wyniki i dyskusja / Results and discussion}

Stan fitosanitarny ziarna był dobry (tab. 1). Najczęściej izolowanym gatunkiem $\mathrm{z}$ nieodkażonego i odkażonego ziarna wszystkich badanych rodów był grzyb gatunku Alternaria alternata, który dominował w całkowitej ilości grzybów. Pozostałe izolowane gatunki - Epicoccum nigrum, Fusarium culmorum, $F$. poae, a na ziarnie odkażonym dodatkowo $F$. graminearum, występowały sporadycznie. Ponadto wyszczególniono grupę określoną jako „pozostałe”, w której ujęto gatunki występujące rzadziej lub o mniejszym znaczeniu dla bezpieczeństwa żywności; dla ziarna nieodkażonego były to: Botrytis cinerea, Nigrospora oryzae, Rhizopus stolonifer i kolonie niezarodnikujące, a dla ziarna odkażonego - Bipolaris sorokiniana, $N$. oryzae, Ulocladium consortiale i kolonie niezarodnikujące.

Tabela 1. Grzyby wyizolowane z ziarna jęczmienia nagiego (liczba izolatów)

Table 1. Fungi isolated from hull-less barley grain (number of isolates)

\begin{tabular}{|c|c|c|c|c|c|c|c|c|c|c|c|c|c|c|}
\hline \multirow[b]{2}{*}{$\begin{array}{l}\text { Ród } \\
\text { Line }\end{array}$} & \multicolumn{2}{|c|}{$\begin{array}{c}\text { Razem } \\
\text { Total }\end{array}$} & \multicolumn{2}{|c|}{ A. alternata } & \multicolumn{2}{|c|}{ E. nigrum } & \multicolumn{2}{|c|}{ F. culmorum } & \multicolumn{2}{|c|}{ F. graminearum } & \multicolumn{2}{|c|}{ F. poae } & \multicolumn{2}{|c|}{$\begin{array}{c}\text { Pozostałe } \\
\text { Others }\end{array}$} \\
\hline & $\begin{array}{l}\mathrm{n} \\
\mathrm{n}\end{array}$ & $\begin{array}{l}\mathrm{o} \\
\mathrm{d}\end{array}$ & $\begin{array}{l}\mathrm{n} \\
\mathrm{n}\end{array}$ & $\begin{array}{l}\mathrm{o} \\
\mathrm{d}\end{array}$ & $\begin{array}{l}\mathrm{n} \\
\mathrm{n}\end{array}$ & $\begin{array}{l}\mathrm{o} \\
\mathrm{d}\end{array}$ & $\begin{array}{l}\mathrm{n} \\
\mathrm{n}\end{array}$ & $\begin{array}{l}\mathrm{o} \\
\mathrm{d}\end{array}$ & $\begin{array}{l}\mathrm{n} \\
\mathrm{n}\end{array}$ & $\begin{array}{l}\mathrm{o} \\
\mathrm{d}\end{array}$ & $\begin{array}{l}\mathrm{n} \\
\mathrm{n}\end{array}$ & $\begin{array}{l}\mathrm{o} \\
\mathrm{d}\end{array}$ & $\begin{array}{l}\mathrm{n} \\
\mathrm{n}\end{array}$ & $\begin{array}{l}\mathrm{o} \\
\mathrm{d}\end{array}$ \\
\hline STH 1192 & 104 & 75 & 78 & 47 & 24 & 5 & 0 & 0 & 0 & 0 & 0 & 0 & 2 & 23 \\
\hline STH 1246 & 91 & 79 & 85 & 62 & 0 & 0 & 0 & 6 & 0 & 0 & 4 & 0 & 2 & 11 \\
\hline STH 1292 & 117 & 91 & 111 & 85 & 6 & 0 & 0 & 0 & 0 & 0 & 0 & 0 & 0 & 6 \\
\hline STH 4933 & 94 & 82 & 69 & 56 & 7 & 0 & 1 & 0 & 0 & 11 & 0 & 7 & 17 & 8 \\
\hline STH 7007 & 110 & 81 & 82 & 50 & 7 & 0 & 0 & 0 & 0 & 0 & 17 & 25 & 4 & 6 \\
\hline STH 7809 & 101 & 92 & 67 & 68 & 1 & 2 & 1 & 2 & 0 & 0 & 19 & 5 & 13 & 15 \\
\hline
\end{tabular}

$\mathrm{n}$ - ziarno nieodkażone, o - ziarno odkażone

$\mathrm{n}$ - non-disinfected grain, $\mathrm{d}-$ disinfected grain 


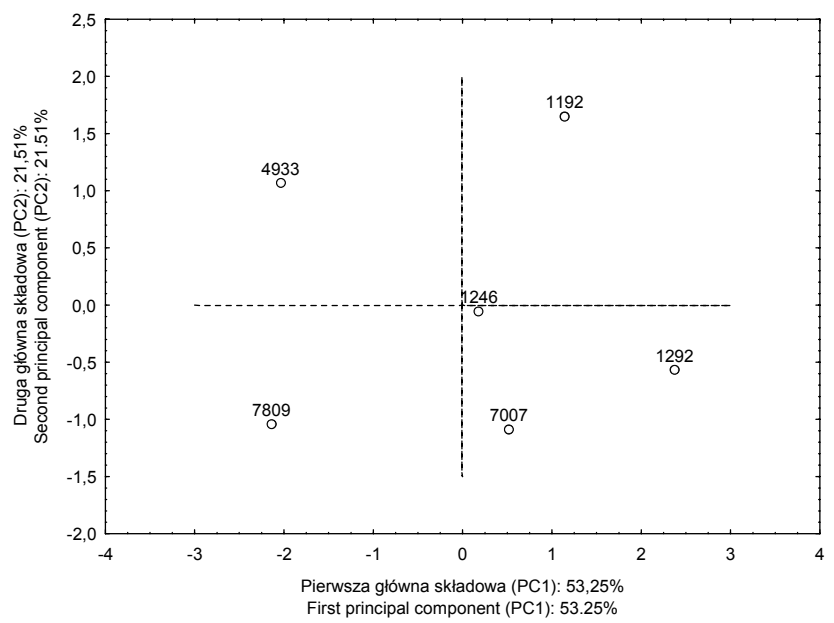

Rys. 1a. Zróżnicowanie rodów jęczmienia według zasiedlenia powierzchni ziarna przez grzyby

Fig. 1a. The differentiation of barley lines depending on the occurrence of fungi on the grain surface

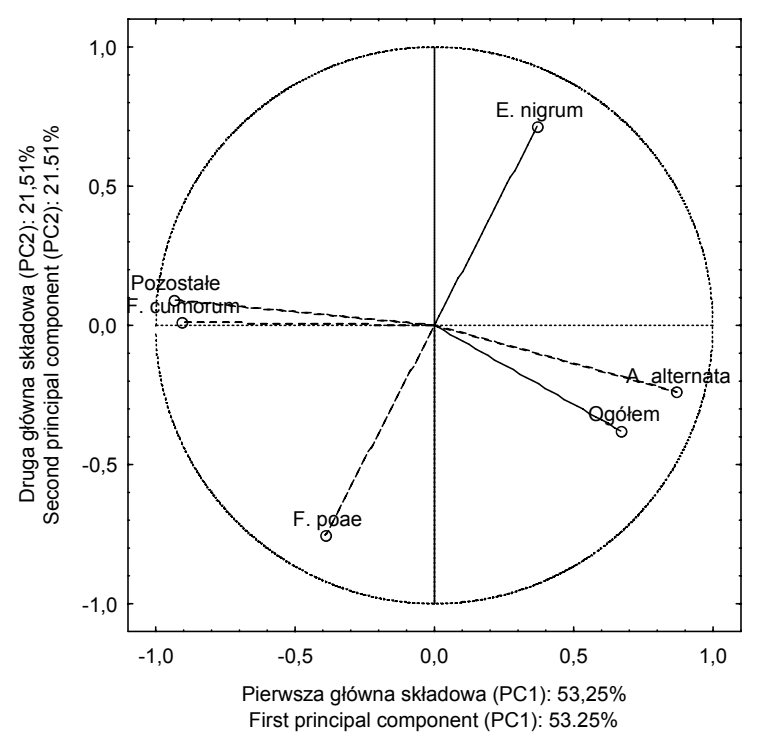

Rys. 1b.Zróżnicowanie występowania grzybów na powierzchni ziarna jęczmienia

Fig. 1b. The differentiation of the occurrence of fungi on the surface of barley grain
Przeprowadzono analizę głównych składowych (PCA principal component analysis) dla ziarna nieodkażonego (rys. 1a). Dla badanych rodów jęczmienia 53,25\% zmienności (pierwsza główna składowa, first principal component - PC1) wynikała z obecności grzybów sklasyfikowanych jako ,pozostałe” i A. alternata. Rody STH 4933 i STH 7809, z których izolowano najwięcej pozostałych kolonii i grzybów z rodzaju Fusarium oraz najmniej $A$. alternata, znalazły się po lewej stronie, natomiast pozostałe rody - po prawej stronie osi 0. Druga główna składowa (second principal component - PC2) wyjaśniła $21,51 \%$ zmienności. W tym przypadku o zmienności badanych prób decydowała przede wszystkim obecność E. nigrum i $F$. poae. Rody, z których izolowano większe ilości $E$. nigrum, znalazły się po jednej stronie osi 0 , a rody $\mathrm{z}$ przewaga $F$. poae $-\mathrm{z}$ przeciwnej strony. Gil i wsp. $(2011,2012)$ wykazali, że te dwa rody korzystnie wyróżniały się na tle pozostałych pod względem masy 1000 ziaren, zawartości białka i prozdrowotnych $\beta$-glukanów. Większa podatność tych rodów na Fusarium spp., pomimo pożądanego składu chemicznego, może być czynnikiem ograniczającym jego potencjalne wykorzystanie w produkcji żywności.

Przyglądając się wzajemnym zależnościom pomiędzy liczebnościami poszczególnych gatunków (rys. 1b) można zauważyć, że występowanie $F$. culmorum było silnie powiązane $\mathrm{z}$ obecnością pozostałych kolonii, co potwierdza korelacja liniowa $(r=0,97)$ (tab. 2), a częstotliwość występowania $A$. alternata dodatnio wpłynęła na całkowitą liczbę grzybów, co jednak nie znalazło tak silnego odzwierciedlenia w korelacji liniowej $(r=0,66)$. PCA wykazała również silną, ujemną zależność pomiędzy występowaniem E. nigrum i $F$. poae, przy czym współczynnik korelacji nie był wysoki $(\mathrm{r}=-0,42)$.

Zasiedlenie głębszych partii ziarna przez grzyby różniło się od występowania grzybów na powierzchni (rys. 2a, tab. 3). Pierwsza główna składowa (PC1) wyjaśniła zaledwie 38,85\% zmienności badanych prób. Zmienność ta wynikała z obecności $E$. nigrum i pozostałych grzybów z jednej strony i A. alternata oraz grzybów ogółem z drugiej strony. Wyróżniającym się pod tym względem był ród STH 1192. Z jego ziarna po powierzchniowym

Tabela 2. Współzależności występowania grzybów na nieodkażonym ziarnie jęczmienia

Table 2. Correlation between the occurrence of fungi on non-disinfected hull-less barley grain

\begin{tabular}{|c|c|c|c|c|c|c|}
\hline & $\begin{array}{c}\text { Razem } \\
\text { Total }\end{array}$ & A. alternata & E. nigrum & F. culmorum & F.poae & $\begin{array}{c}\text { Pozostałe } \\
\text { Others }\end{array}$ \\
\hline $\begin{array}{l}\text { Razem } \\
\text { Total }\end{array}$ & 1,00 & & & & & \\
\hline A. alternata & 0,66 & 1,00 & & & & \\
\hline E. nigrum & 0,24 & $-0,04$ & 1,00 & & & \\
\hline F. culmorum & $-0,42$ & $-0,68$ & $-0,31$ & 1,00 & & \\
\hline F.poae & 0,09 & $-0,38$ & $-0,42$ & 0,25 & 1,00 & \\
\hline $\begin{array}{l}\text { Pozostałe } \\
\text { Others }\end{array}$ & $-0,49$ & $-0,76$ & $-0,26$ & $0,97 *$ & 0,22 & 1,00 \\
\hline
\end{tabular}

*korelacja istotna, $\mathrm{p}=0,95$ - significant correlation, $\mathrm{p}=0.95$ 
Tabela 3. Współzależności występowania grzybów na odkażonym ziarnie jęczmienia

Table 3. Correlation between the occurrence of fungi on disinfected hull-less barley grain

\begin{tabular}{l|c|c|c|c|c|c|c}
\hline & $\begin{array}{c}\text { Razem } \\
\text { Total }\end{array}$ & A. alternata & E. nigrum & F. culmorum & F. graminearum & F. poae & $\begin{array}{c}\text { Pozostałe } \\
\text { Others }\end{array}$ \\
\hline $\begin{array}{l}\text { Razem } \\
\text { Total }\end{array}$ & 1,00 & & & & & & \\
\hline A. alternata & $0,83^{*}$ & 1,00 & & & & & \\
\hline E. nigrum & $-0,35$ & $-0,41$ & 1,00 & & & & \\
\hline F. culmorum & $-0,11$ & 0,10 & $-0,22$ & 1,00 & & & \\
\hline F. graminearum & $-0,10$ & $-0,19$ & $-0,28$ & $-0,27$ & 1,00 & & \\
\hline F. poae & $-0,07$ & $-0,43$ & $-0,33$ & $-0,33$ & 0,04 & 1,00 & \\
\hline $\begin{array}{l}\text { Pozostałe } \\
\text { Others }\end{array}$ & $-0,39$ & $-0,42$ & $0,96^{*}$ & 0,05 & $-0,26$ & $-0,45$ & 1,00 \\
\hline
\end{tabular}

*korelacja istotna, $\mathrm{p}=0,95$ - significant correlation, $\mathrm{p}=0.95$

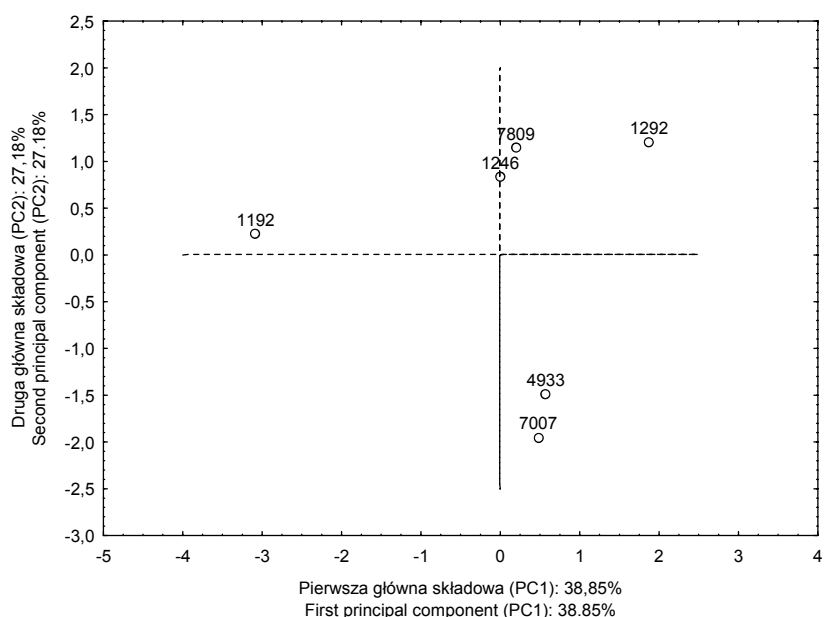

Rys. 2a. Zróżnicowanie rodów jęczmienia według zasiedlenia głębszych partii ziarna przez grzyby

Fig. 2a. The differentiation of barley lines depending on the occurrence of fungi in the grain deeper tissues

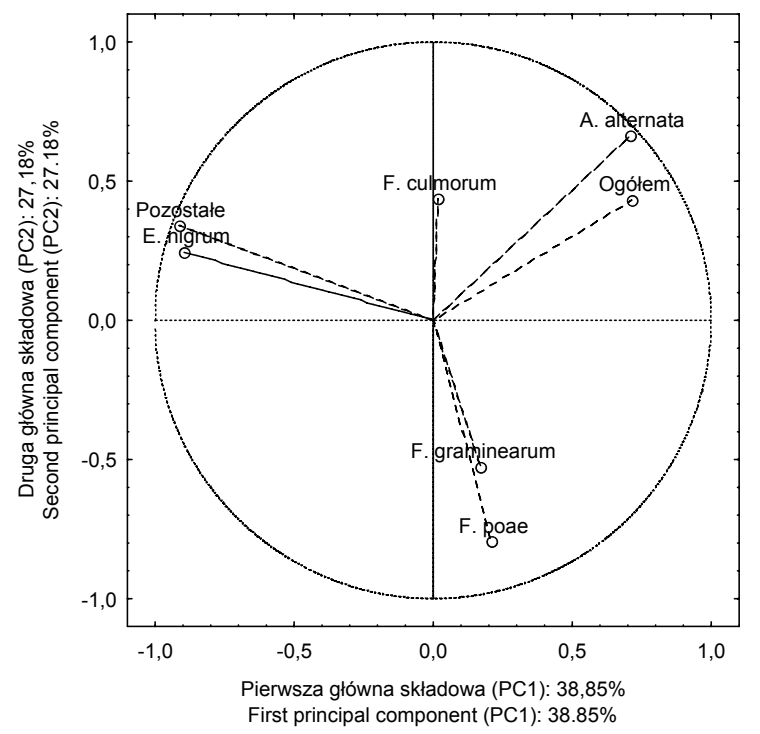

Rys. 2b.Zróżnicowanie występowania grzybów w głębszych partiach ziarna jęczmienia

Fig. 2b. The differentiation of barley lines depending on the occurrence of fungi in the deeper tissues of barley grain odkażeniu izolowano najmniej kolonii A. alternata, a najwięcej - E. nigrum oraz ,pozostałych” grzybów. Z kolei 27,18\% zmienności (druga główna składowa, PC2) wynikało przede wszystkim z obecności $F$. graminearum i $F$. poae, a po przeciwnej stronie - A. alternata. Rodami silniej zasiedlonymi przez $F$. graminearum i $F$. poae, i tym samym wyróżniającymi się spośród badanych prób, były STH 4933 i STH 7007.

Analizując powiązania pomiędzy gatunkami grzybów, daje się zauważyć dwie silne zależności (rys. 2b, tab. 3). E. nigrum był bardzo mocno związany z ,pozostałymi” grzybami $(\mathrm{r}=0,96)$, natomiast $A$. alternata był dodatnio skorelowany z grzybami ogółem $(\mathrm{r}=0,83)$. Na podstawie PCA można wyróżnić jeszcze jedną parę - $F$. graminearum i $F$. poae, jednak korelacja liniowa Pearsona nie potwierdza tej zależności $(\mathrm{r}=0,04)$.

Skład gatunkowy grzybów zasiedlających ziarno jęczmienia różni się $\mathrm{w}$ zależności od tego, czy jest to ziarno bezpośrednio po zbiorach, czy też przechowywane. Świeże ziarno zasiedlane jest przede wszystkim przez A. alternata i rodzaj Fusarium, natomiast na ziarnie przechowywanym dominują grzyby z rodzaju Aspergillus i Penicillium (Rabie i wsp. 1997; Narkiewicz-Jodko 1998). Baturo-Cieśniewska (2011) wykazała, że grzybami najczęściej występującymi na ziarnie jęczmienia pochodzącym z upraw ekologicznych są A. alternata, B. sorokiniana i E. nigrum, a częstotliwość występowania grzybów z rodzaju Fusarium jest mniejsza. Wysokie liczebności $A$. alternata i $E$. nigrum są zbieżne z wynikami własnymi, natomiast nie ma zgodności co do częstotliwości występowania B. sorokiniana i rodzaju Fusarium. Podobne wyniki uzyskali Mazurkiewicz i wsp. (2008), do najczęściej występujących grzybów na ziarnie jęczmienia, niezależnie od systemu uprawy, należą rodzaj Alternata oraz $F$. poae przy jednoczesnym dużym udziale grzybów niezarodnikujących, co również zauważono w obecnej pracy. Z kolei Ioos i wsp. (2004) zaobserwowali silny wpływ warunków pogodowych i glebowych na częstotliwość występowania poszczególnych gatunków z rodzaju Fusarium, niemniej najczęściej izolowanymi gatunkami we Francji były: $F$. avenaceum, $F$. graminearum, $F$. culmorum i $F$. poae. Autorzy ci zwrócili również uwagę na zdolność tych gatunków do tworzenia mikotoksyn. F. graminearum jest odpowiedzialny za wytwarzanie deoksyni- 
walenolu (DON) i niwalenolu (NIV), F. poae - niwalenolu. $F$. avenaceum nie posiada zdolności syntezowania trichotecenów, natomiast wytwarza moniliforminy. Baturo-Cieśniewska (2011) uzyskała całkiem inne wyniki, gdyż wykazała, że jęczmień z upraw ekologicznych porażany jest głównie przez B. sorokiniana, Drechslera teres i grzyby z rodzaju Fusarium.

W zależności od tego, czy bada się ziarno nieodkażone, czy odkażone, istnieją różnice w liczebności poszczególnych gatunków grzybów (Narkiewicz-Jodko i wsp. 2008). W obu przypadkach, podobnie jak we wszystkich przytaczanych pracach, dominował $A$. alternata, natomiast drugim co do liczebności w przypadku powierzchni ziarna był rodzaj Fusarium, a po powierzchniowym odkażeniu $B$. sorokiniana. W obecnej pracy $B$. sorokiniana był bardzo rzadko izolowany, co może wskazywać na niekorzystne dla jego rozwoju warunki pogodowe panujące w czasie wegetacji roślin lub odporność jęczmienia nagiego na infekcję tym gatunkiem.

\section{Wnioski / Conclusions}

1. Liczba izolowanych grzybów w badaniu była niewielka, co wskazuje na dobrą zdrowotność ocenianego materiału.

2. Istnieją różnice $\mathrm{w}$ zasiedleniu ziarna jęczmienia przez grzyby pomiędzy jego powierzchnią a głębszymi tkankami.

3. Rody jęczmienia różniły się wielkością porażenia przez grzyby w zależności od tego, czy badane jest ziarno nieodkażone, czy odkażone. Jedynie na ziarnie rodu STH 7809 (Gawrosz) skład gatunkowy grzybów w obu przypadkach był zbliżony.

4. Najliczniejszym gatunkiem w całkowitej liczbie izolowanych grzybów był grzyb A. alternata, a wyróżniającym się pod tym względem był ród STH 1292.

Praca naukowa finansowana ze środków Narodowego Centrum Nauki w ramach projektu badawczego nr N N312 446340.

\section{Literatura / References}

Baturo-Cieśniewska A. 2011. Grzyby zasiedlające ziarno dziewięciu odmian jęczmienia jarego w pierwszym roku uprawy w systemie ekologicznym. Prog. Plant Prot./Post. Ochr. Roślin 51 (2): 822-826.

Barnett H.L., Hunter B.B. 1972. Illustrated Genera of Imperfect Fungi. Burges Publishing Company. Minneapolis, Minnesota, USA, $241 \mathrm{pp}$.

Booth C. 1971. The Genus Fusarium. Commonwealth Mycological Institute, Kew, Surrey, England, 237 pp.

Ellis M.B. 1971. Dematiaceous Hyphomycetes. Commonwealth Mycological Institute, Kew, Surrey, England, 608 pp.

Gil Z., Mularczyk A., Wojciechowicz A., Łukaszewicz M., Nita Z. 2012. Charaterystyka jakościowa ziarna nowych rodów jęczmienia nagoziarnowego. s. 20-21. W: Materiały Konferencji „Jakość a wykorzystanie ziarna zbóż”. Puławy, IUNG, 18-19 października 2012,82 ss.

Gil Z., Wojciechowicz A., Spychaj R., Kościelak N., Mularczyk A., Nita Z. 2011. Quality characteristic of new hull-less barley genotypes with high level beta-glucan. p. 139-148. In: „Selected Problems of Nutraceutical and Functional Food” (T. Trziszka, Ł. Bobak, M. Kaźmierska, eds.). Wydawnictwo Uniwersytetu Przyrodniczego we Wrocławiu, Wrocław.

Ioos R., Belhadj A., Menez M. 2004. Occurrence and distribution of Microdochium nivale and Fusarium species isolated from barley, durum and soft wheat grains in France from 2000 to 2002. Mycopathologia 158: 351-362.

Malone J.P., Muskett A.E. 1964. Seed-borne fungi. Proc. Int. Seed Testing Association 29 (2), 384 pp.

Mazurkiewicz J., Solarska E., Muszyńska M., Kuzdraliński A. 2008. Występowanie trichotecenów fuzaryjnych w jęczmieniu jarym z systemów produkcji ekologicznej i konwencjonalnej. Prog. Plant Prot./Post. Ochr. Roślin 48 (2): 426-429.

Narkiewicz-Jodko M. 1998. Zdrowotność ziarna zbóż jako wskaźnik jego jakości. Zesz. Nauk. AR Wrocław. Technologia Żywności XII. 328: 85-93.

Narkiewicz-Jodko M., Mularczyk A., Urban M. 2008. Wpływ fungicydów na jakość i zdrowotność ziarna jęczmienia jarego. Prog. Plant Prot./Post. Ochr. Roślin 48 (1): 237-245.

Rabie C.J., Lübben A., Marais G.J., Jansen van Vuuren H. 1997. Enumeration of fungi in barley. Int. J. Food Microbiol. 35 (1997): $117-127$. 